DOI: $10.20961 / j p s c r . v 3 i 2.22200$

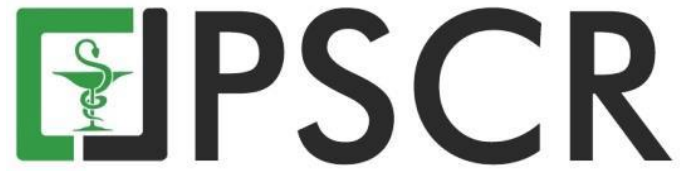

\title{
Evaluasi Ketepatan Obat dan Dosis Obat Anti Tuberkulosis pada Pasien Anak Di Instalasi Rawat Jalan RSUDDr. Moewardi Surakarta Periode 2016-2017
}

\author{
Sawitri Avica Pradani ${ }^{1}$ dan Wisnu Kundarto ${ }^{1 *}$ \\ ${ }^{1}$ Program Studi D3 Farmasi, Fakultas Matematika dan Ilmu Pengetahuan Alam, Universitas Sebelas Maret \\ *email korespondensi: wisnukundarto.apt@gmail.com
}

\begin{abstract}
Abstrak: TB anak adalah penyakit yang disebabkan oleh Mycobacterium tuberculosis pada usia 0-14 tahun. Adanya kesulitan dalam aspek diagnosis TB anak seringkali menimbulkan terjadinya over diagnosis dan over treatment. Penggunaan OAT pada pasien anak di Surakarta belum memenuhi ketepatan dosis $100 \%$. Penelitian ini bertujuan untuk mengevaluasi penggunaan OAT pada anak di Instalasi Rawat Jalan RSUD Dr. Moewardi meliputi tepat obat, dan dosis. Penelitian ini merupakan penelitian non eksperimental dengan jenis penelitian deskriptif. Pengumpulan data dilakukan secara retrospektif. Populasi terjangkau pada penelitian ini yaitu pasien TB anak usia 0-14 tahun di Instalasi Rawat Jalan RSUD Dr. Moewardi pada periode Januari 2016 - Desember 2017. Teknik pengambilan sampel yang digunakan yaitu teknik consecutive sampling. Kriteria inklusi pada penelitian ini yaitu pasien yang baru terdiagnosis TB dengan atau tanpa penyakit penyerta lain, mendapat terapi TB minimal 6 bulan, dan memiliki kelengkapan data rekam medik. Analisis data dilakukan dengan metode analisa deskriptif untuk mengetahui gambaran karakteristik pasien TB anak, pola dan evaluasi penggunaan OAT yang disajikan dalam bentuk persentase. Analisis ketepatan penggunaan obat dan dosis berpedoman pada Pedoman Nasional Pengendalian Tuberkulosis 2014. Penelitian ini melibatkan 21 pasien dengan didiagnosis TB Paru 16 pasein dan TB ekstra paru 5 pasien. Dari total pasien, 11 pasien tanpa penyerta, dan 10 pasien memiliki penyakit penyerta. HIV merupakan penyakit penyerta terbanyak yang diderita pasien. Ketepatan obat pada semua fase pengobatan $100 \%$ dan ketidaktepatan dosis sebanyak 5,3\% yaitu mengalami subdosis pada fase pengobatan intensif. Berdasarkan hasil penelitian perlu dilakukan penelitian lebih lanjut secara prospektif tentang monitoring efek samping obat.
\end{abstract}

Kata kunci: Tepat obat; Tepat dosis; Obat anti-tuberkulosis; Pasien anak

Abstract: Evaluation of Drug Rationality and Dosage of Anti Tuberculosis Drugs in Pediatric Outpatient of RSUD Dr. Moewardi, Surakarta Period in 2016-2017. Pediatric tuberculosis is a disease caused by Mycobacterium tuberculosis at the age of 0 to 14 years. The difficulty in the pediatric tuberculosis diagnosis aspect often result in over diagnosis and over treatment. The use of anti-tuberculosis drugs in Surakarta have not achieved 100\% right dosage. This research aimed to evaluate the use of anti-tuberculosis drugs including right drug, and right dosage in pediatric outpatient of RSUD Dr. Moewardi. This research was a non-experimental research with descriptive research type. Data collection was conducted retrospectively. The accessible population was this research is pediatric tuberculosis patients aged from 0 to 14 years old at outpatient installation of RSUD Dr. Moewardi in the period of January 2016 to December 2017. The sample collection technique used was consecutive sampling technique. Inclusion 
criteria in this research were the new pediatric tuberculosis patients aged from 0 to 14 years old, have received tuberculosis therapy at least for 6 month, have been diagnosed with tuberculosis with or without comorbidities, and have completed medical record data. Data analysis was carried out using descriptive analysis method to find out the characteristics of pediatric tuberculosis patients, pattern and evaluation of the use of anti-tuberculosis drugs which was presented in the form of percentage. The analysis of drug use and dosage rationality was guided by National Control Management Tuberculosis Guideline 2014. This research conducted data from 21 patients consist of 16 patient diagnose TB pulmonary and 5 patient diagnose TB extrapulmonary . From total patient, 11 patients without co-morbidities and 10 of them had comorbidities. HIV was the most common comorbid disease suffered by patients. The drug rationality percentage at all phases was $100 \%$ and the use of irrational fixed-dose drugs was $5,3 \%$ marked by sub-dose at intensive treatment phase. Based on the results, researcher suggested to further prospective approach research about monitoring drug side effects.

Keywords: Right drug; Right dosage; Anti-tuberculosis drugs; Pediatric patients

\section{Pendahuluan}

Tuberkulosis (TB) anak adalah penyakit menular langsung yang disebabkan oleh Mycobacterium tuberculosis pada anak usia 0-14 tahun. Menurut Kementerian Kesehatan Republik Indonesia tahun 2013, banyak anak penderita TB yang diperkirakan tidak mendapatkan penatalaksanaan yang tepat dan benar sesuai dengan ketentuan strategi Directly Observed Treatment Short Course (DOTS). Jumlah kasus TB paru pada anak yang tercatat di Kota Surakarta tahun 2014 sebanyak 85 kasus, tahun 2015 sebanyak 14 kasus dan tahun 2016 mengalami peningkatan jika dibandingkan dengan tahun sebelumnya sebanyak 89 kasus (Dinkes Surakarta, 2014).

TB anak mempunyai permasalahan khusus yang berbeda dengan orang dewasa. Pemeriksaan TB yang memerlukan sampel dahak dari sang anak masih sulit diterapkan. Kesulitan dan keraguan dalam aspek diagnosis ini seringkali menimbulkan terjadinya over diagnosis dan over treatment dalam penanganan TB anak (Senewe, 2002). Kegagalan pengobatan TB, umumnya disebabkan karena pengobatan yang terlalu singkat, tidak teratur dan obat kombinasi yang tidak tepat (Muniroh, dkk., 2013). Pengobatan TB yang memerlukan waktu panjang, dapat menyebabkan kurangnya tingkat kepatuhan pasien dalam minum obat, sehingga akan mempengaruhi keberhasilan terapi. Rendahnya tingkat kepatuhan pasien, dan ketidaktepatan pemberian obat anti-tuberkulosis (OAT) akan menyebabkan timbulnya Multi Drug Resistence (MDR), hingga terjadinya kegagalan terapi TB (Tricahyono, 2013).

Penelitian Dewi (2011) di Instalasi Rawat Jalan BKPM Klaten menyatakan bahwa ketepatan dosis penggunan OAT kombipak pada pasien anak sebesar 95\%. Penelitian Tricahyono (2013) di BBKPM Surakarta menyatakan bahwa ketidaktepatan dosis pada pasien anak sebesar 3\% terjadi pada pemberian rifampisin baik tahap intensif maupun pada lanjutan. 
Penelitian Astuti (2010) di Instalasi Rawat Jalan RSUD Dr. Moewardi menyatakan bahwa penggunaan OAT kombipak pada pasien dewasa sebesar $86,21 \%$ dikategorikan tepat dosis. Berdasarkan latar belakang tersebut, didukung dengan belum banyaknya penelitian yang spesifik mengenai evaluasi penggunaan OAT pada pasien anak khususnya di Kota Surakarta, serta penelitian terdahulu yang telah dilakukan oleh Tricahyono (2013) dan Astuti (2010) belum memenuhi ketepatan dosis $100 \%$, maka penelitian ini diharapkan mampu memberikan evaluasi ketepatan obat dan dosis pada pasien TB anak kasus baru selama periode Januari 2016 Desember 2017 di Instalasi Rawat Jalan RSUD Dr. Moewardi.

\section{Metode Penelitian}

Penelitian ini merupakan penelitian non eksperimental dengan jenis penelitian deskriptif. Pengumpulan data dilakukan secara retrospektif. Penelitian dilakukan pada bulan Februari Maret 2018 di Poli Anak RSUD Dr. Moewardi. Populasi target pada penelitian ini adalah semua pasien TB anak di Instalasi Rawat Jalan RSUD Moewardi mulai 1 Januari 2016 - 31 Desember 2017. Populasi terjangkau yang ditetapkan pada penelitian ini yaitu pasien TB anak usia $0-14$ tahun di Instalasi Rawat Jalan RSUD Dr. Moewardi mulai 1 Januari 2016 - 31 Desember 2017. Sampel yang digunakan pada penelitian ini adalah sebagian dari populasi terjangkau yang datanya tertulis pada rekam medik memenuhi kriteria inklusi. Teknik pengambilan sampel menggunakan teknik consecutive sampling. Kriteria inklusi pada penelitian ini yaitu pasien yang baru terdiagnosis TB dengan atau tanpa penyakit penyerta lain, usia $0-14$ tahun, mendapat terapi TB minimal 6 bulan, serta memiliki kelengkapan data rekam medik, meliputi nama pasien, jenis kelamin pasien, umur pasien, obat yang digunakan, lama pengobatan, intensitas control, berat badan pasien, dan data laboratorium.

Alat penelitian yang digunakan adalah lembar pengumpulan data serta guideline pengobatan TB pada anak menurut Pedoman Nasional Pengendalian Tuberkulosis tahun 2014 (Kemenkes RI, 2014). Bahan yang digunakan dalam penelitian adalah data rekam medik pasien TB anak di RSUD Dr. Moewardi.

Analisis data dilakukan dengan metode analisa deskriptif untuk memberikan gambaran karakteristik pasien TB anak, pola dan evaluasi penggunaan OAT pada pasien meliputi tepat obat, dan tepat dosis. Data yang diperoleh disajikan dalam bentuk persentase.

\section{Hasil dan Pembahasan}

Berdasarkan hasil penelitian, diperoleh data sejumlah 21 pasien memenuhi kriteria inklusi. Data yang diperoleh kemudian diolah, sehingga dapat diketahui gambaran karakteristik pasien dan pola penggunaan obat. 


\subsection{Karakteristik pasien}

Adapun karakteristik pasien dapat dilihat pada Tabel 1. Berdasarkan hasil penelitian, distribusi pasien dengan jenis kelamin laki - laki (66,67\%) dan perempuan $(33,33 \%)$. Hal ini, menunjukkan bahwa laki-laki dan perempuan mempunyai risiko yang sama untuk terkena infeksi TB karena jenis kelamin tidak mempengaruhi penularan TB maupun infeksi bakteri TB pada anak. Distribusi pasien TB anak berdasarkan usia, dapat diketahui kelompok usia 0-4 tahun lebih banyak (57,14\%). Menurut Raharjoe (2008), pasien dengan usia $\leq 5$ tahun berisiko lebih besar mengalami progresi infeksi menjadi sakit TB. Hal ini disebabkan karena pasien belum mengalami perkembangan imunitas seluler yang sempurna.

Pasien yang didiagnosis TB paru lebih banyak pada penelitian ini, yaitu 76,19\%. Penelitian Miftahurrahmah, dkk. (2014) menyebutkan sebanyak 87,5\% dari subyek penelitian didiagnosis TB paru dan 12,5\% pasien anak menderita TB ekstra paru yang terdiri dari TB meningitis, TB spondilitis dan skrofuloderma. Penyakit penyerta terbanyak yang diderita pasien TB anak yaitu HIV. Pasien TB anak yang terinfeksi HIV harus memperhatikan keadaan klinis dan imunologis anak agar dapat menentukan waktu pemberian OAT yang tepat. Pasien TB dengan penyakit penyerta HIV akan mengalami kerusakan sistem imun sehingga bakteri TB yang dorman mengalami aktivasi (Kartasasmita, 2009).

Lama pengobatan pasien telah sesuai dengan standar TB Nasional tahun 2014, yaitu pengobatan yang dianjurkan adalah pengobatan 6 bulan atau lebih, baik pada pengobatan kasus TB paru maupun TB ekstra paru. Hasil dari penelitian ini, dapat diketahui bahwa 16 sampel penelitian dinyatakan sembuh, sedangkan 5 pasien lainnya masih dalam masa pengobatan. Penelitian Dewi (2011) di Instalasi Rawat Jalan BKPM Klaten menyebutkan bahwa sebanyak 35 $(87,5 \%)$ pasien anak TB paru dinyatakan sembuh dan 5 (12,5\%) pasien anak tidak diketahui hasil pengobatannya karena pindah ke unit pelayanan kesehatan yang lain.

\subsection{Pola penggunaan obat}

Penggunaan OAT pada pasien anak di Instalasi Rawat Jalan RSUD Dr. Moewardi periode 2016-2017 sudah sesuai dengan drug of choice menurut Pedoman Nasional Pengendalian Tuberkulosis tahun 2014. Penggunaan OAT diberikan dalam bentuk kombinasi minimal 3 macam obat untuk mencegah terjadinya resistensi obat dan untuk membunuh kuman intraseluler atau ekstraseluler (Kemenkes, 2014). Adapun penggunaan regimen OAT pada pasien baru dilihat pada Tabel 2 . 
Tabel 1. Karakteristik TB anak rawat jalan di RSUD Dr. Moewardi periode 2016-2017

\begin{tabular}{lcc}
\hline \multicolumn{1}{c}{ Keterangan } & Jumlah & \% \\
\hline 1. Jenis Kelamin & 14 & 66,67 \\
a. Laki-laki & 7 & 33,33 \\
b. Perempuan & & \\
\hline 2. Usia & 12 & 57,14 \\
a. 0-4 tahun & 9 & 42,86 \\
b. 5-14 tahun & & \\
\hline 3. Lokasi anatomi penyakit & 16 & 76,19 \\
a. TB Paru & 12 & \\
1.) TB Ringan & 1 & \\
2.) TB Milier & 3 & \\
3.) TB Destroyed Lungs & 5 & 23,81 \\
b. TB Ekstra Paru & 1 & \\
1.) TB Meningitis & 3 & \\
2.) TB Sponditilis & 1 & \\
3.) TB Efusi pleura & & \\
4. Penyakit penyerta & 11 & 52,38 \\
a. Tanpa penyerta & 10 & 47,61 \\
b. Dengan penyerta & 3 & \\
1.) HIV & 1 & \\
2.) Stomatitis & 1 & \\
3.) Epilepsi & 1 & \\
4.) Utikaria & 1 & \\
5.) Atrial Septal Defect & 1 & \\
6.) Pneumonia & 1 & \\
7.) Mitral \& Tricuspid regurgitation (MR \& TR mild) & 1 & \\
8.) Penyakit Jantung Reumatik \& kardiomiopati & 1 & \\
9.) Pneumocystis Pneumonia & & \\
10.) Colli sinistra abses & & \\
Lama pengobatan & 1 & \\
\hline & & \\
\hline
\end{tabular}

5. Lama pengobatan
a. $<6$ bulan
$0 \quad 0$
b. 6 bulan
$12 \quad 57,14$
c. $>6$ bulan
9
42,86

6. Hasil pengobatan
a. Sembuh
16
100
b. Pengobatan lengkap, default, pindah gagal
0

Penggunaan regimen $\mathrm{R} / \mathrm{H} / \mathrm{Z}+\mathrm{E}$ sudah sesuai yaitu digunakan pada awal pengobatan tahap intensif, karena pasien didiagnosis TB dengan kondisi tertentu seperti TB milier, TB destroyed lung, TB paru efusi pleura dengan BTA positif, meningitis TB, TB paru dengan penyerta HIV, dan sponditilis TB tersangka MDR. Penggunaan OAT pada pasien anak di Instalasi Rawat Jalan RSUD Dr. Moewardi diberikan dalam bentuk paket berupa obat Kombinasi Dosis Tetap (KDT) dan atau dalam bentuk kombipak. Penggunaan OAT KDT ini 
dapat menurunkan MDR karena kepatuhan pasien dalam minum obat meningkat. Penggunaan OAT KDT juga memiliki kelemahan yaitu jika terjadi efek samping tidak dapat diketahui obat mana yang menyebabkan terjadinya efek samping termasuk hepatotoksisitas (Khoirunisa, 2015). Adapun pola peresepan obat fase intensif dapat dilihat pada Tabel 3.

Tabel 2. Pola penggunaan obat regimen OAT pada pasien anak di Instalasi Rawat Jalan RSUD Dr. Moewardi periode 2016-2017, R = Rifampisin H= Isoniazid Z= Pirazinamid E= Etambutol

\begin{tabular}{ccc}
\hline Penggunaan OAT & Jumlah & \% \\
\hline $\mathrm{R} / \mathrm{H} / \mathrm{Z}+\mathrm{E}$ & 9 & 42,86 \\
$\mathrm{R} / \mathrm{H} / \mathrm{Z}$ & 12 & 57,14 \\
Total & $\mathbf{2 1}$ & $\mathbf{1 0 0}$ \\
\hline
\end{tabular}

Tabel 3. Pola penggunaan obat fase intensif pada pasien anak di Instalasi Rawat Jalan RSUD Dr. Moewardi $(n=21)$, Kombinasi Dosis Tetap (KDT) dan Fixed Dose Combination (FDC)

\begin{tabular}{ccc}
\hline Pola penggunaan obat Fase Intensif & Jumlah Peresepan & $\boldsymbol{\%}$ \\
\hline Kombipak & 21 & 47,73 \\
KDT/FDC & 23 & 52,27 \\
Total & $\mathbf{4 4}$ & $\mathbf{1 0 0}$ \\
\hline
\end{tabular}

Pola peresepan obat pada fase lanjutan pada pasien Tabel 4. penggunaan OAT paket KDT lebih banyak digunakan pada fase lanjutan. Masih cukup banyaknya penggunaan OAT kombipak dapat digunakan untuk mempermudah mengetahui komponen obat yang kemungkinan dapat menyebabkan terjadinya efek samping pada sampel penelitian akibat penggunaan OAT. Penggunaan OAT kombipak juga dapat mencegah adanya efek samping hepatotoksisitas. Penelitian Priyandani, dkk., (2014) menyebutkan dari hasil penelitian dapat diketahui bahwa pengobatan TB menggunakan OAT paket KDT serta tidak ada pasien TB yang diberikan obat kemasan kombipak karena tidak ada pasien TB yang mengalami efek samping berat sampai harus mengganti dengan OAT kombipak.

Tabel 4. Pola penggunaan obat fase lanjutan pasien anak di Instalasi Rawat Jalan RSUD Dr. Moewardi $(n=21)$, Kombinasi Dosis Tetap (KDT) dan Fixed Dose Combination (FDC)

\begin{tabular}{ccc}
\hline Pola penggunaan obat Fase Lanjutan & Jumlah Peresepan & $\mathbf{\%}$ \\
\hline Kombipak & 29 & 26,85 \\
KDT/FDC & 79 & 73,15 \\
Total & $\mathbf{1 0 8}$ & $\mathbf{1 0 0}$ \\
\hline
\end{tabular}

\subsection{Penggunaan obat lain}

Penggunaan obat lain terbanyak berdasarkan hasil penelitian ini yaitu vitamin dan mineral. Penggunaan OAT rifampisin salah satunya dapat menyebabkan hilangnya nafsu makan, 
sehingga diperlukan pemberian obat penambah nafsu makan. Penggunaan Elkana® dan Likurmin ${ }^{\circledR}$ pada peresepan tersebut sebagai vitamin sekaligus penambah nafsu makan (Tricahyono, 2013). Peresepan Vitamin B6 paling banyak diantara vitamin lainnya, sebab efek samping yang biasa ditimbulkan karena penggunaan OAT Isoniazid yaitu kesemutan sampai dengan rasa terbakar di kaki. Menurut Pedoman Nasional Pengendalian Tuberkulosis tahun 2014, untuk meminimalisir efek samping tersebut dilakukan dengan cara memberikan Vitamin B6.

Persentase penggunaan obat lain yang cukup banyak yaitu kortikosteroid. Penggunaan obat kortikosteroid hanya digunakan pada pasien TB dalam keadaan khusus seperti meningitis TB dengan gangguan kesadaran dan dampak neurologis, TB milier dengan atau tanpa meningitis, efusi pleura dengan gangguan pernafasan berat atau efusi pericardial, dan hipersensitivitas berat terhadap OAT. Penggunaan prednison secara per oral pada anak $2 \mathrm{mg} / \mathrm{kgBB}$, sekali sehari pada pagi hari. Apabila pengobatan diberikan sampai atau lebih dari 4 minggu, dosis harus diturunkan secara bertahap (tappering off) (Kemenkes, 2014). Penggunaan obat lain pada pasien dapat dilihat pada Tabel 5 .

Tabel 5. Penggunaan obat lain pada pasien TB anak di Instalasi Rawat Jalan RSUD Dr.Moewardi Periode 2016-2017

\begin{tabular}{|c|c|c|c|}
\hline No & Jenis Obat & Jumlah & $\%$ \\
\hline 1. & $\begin{array}{l}\text { Vitamin : B6, B9, B12, B kompleks, C, D, Ferris }{ }^{\circledR}, \text { Elkana }^{\circledR} \text {, } \\
\text { Likurmin }^{\circledR}\end{array}$ & 10 & 47,62 \\
\hline 2. & Kortikosteroid : Deksametason, Prednison & 6 & 28,57 \\
\hline 3. & $\begin{array}{l}\text { Antibiotik : Amoxicillin, Cefadroxil, Ampicillin, Gentamicin, } \\
\text { Cefixim, Phenoxymethil penicillin, Eritromisin, Cotrimoxazole }\end{array}$ & 5 & 23,80 \\
\hline 4. & Analgetik antipiretik: Paracetamol, aspirin & 4 & 19,04 \\
\hline 5. & Antiretroviral & 3 & 14,28 \\
\hline 6. & Antihistamin : Cetirizin & 2 & 9,52 \\
\hline 7. & Ekspektoran : Ambroxol & 1 & 4,76 \\
\hline 8. & Diuretik : Furosemid & 1 & 4,76 \\
\hline 9 & ACE Inhibitor : Captopril & 1 & 4,76 \\
\hline 10. & Antifungi : Kandistatin & 1 & 4,76 \\
\hline 11. & Antidiare: Zinc & 1 & 4,76 \\
\hline
\end{tabular}

\subsection{Evaluasi penggunaan obat anti tuberkulosis}

\subsubsection{Tepat obat}

Tepat obat adalah pemilihan obat sesuai dengan drug of choice pengobatan TB setelah diagnosis ditegakkan dengan benar. Penggunaan obat yang dipilih harus memiliki efek terapi sesuai dengan spektrum penyakit dan mempertimbangkan manfaat dan keamanan obat. Adapun 
ketepatan penggunaan obat fase intensif dan fase lanjutan pada pasien dapat dilihat pada Tabel 6 dan Tabel 7.

Tabel 6. Ketepatan penggunaan obat fase intensif pada pasien baru TB anak di Instalasi Rawat Jalan RSUD Dr. Moewardi periode 2016-2017

\begin{tabular}{ccc}
\hline Ketepatan penggunaan obat fase intensif & Jumlah & $\boldsymbol{\%}$ \\
\hline Tepat obat & 21 & 100 \\
Tidak tepat obat & 0 & 0 \\
Total & $\mathbf{2 1}$ & $\mathbf{1 0 0}$ \\
\hline
\end{tabular}

Tabel 7. Ketepatan penggunaan obat fase lanjutan pada pasien baru TB anak di Instalasi Rawat Jalan RSUD Dr. Moewardi periode 2016-2017. Tanda asterisk (*) menunjukkan bahwa 5 pasien sedang dalam tahap menyelesaikan pengobatan

\begin{tabular}{ccc}
\hline Ketepatan penggunaan obat fase lanjutan & Jumlah & $\boldsymbol{\%}$ \\
\hline Tepat obat & $16^{*}$ & 100 \\
Tidak tepat obat & 0 & 0 \\
Total & $\mathbf{1 6}$ & $\mathbf{1 0 0}$ \\
\hline
\end{tabular}

Berdasarkan hasil tersebut dapat diketahui bahwa ketepatan penggunaan obat pada fase lanjutan tidak dapat dievaluasi semuanya, sebab 5 pasien masih dalam tahap menyelesaikan pengobatan. Penggunaan OAT fase intensif dan fase lanjutan pada pasien baru TB anak di Instalasi Rawat Jalan RSUD Dr. Moewardi periode 2016-2017 dapat dikatakan sudah memenuhi kriteria tepat obat berdasarkan Pedoman Nasional Pengendalian Tuberkulosis tahun 2014. Berdasarkan penelitian Dewi (2011) dan Tricahyono (2013), menyatakan bahwa ketepatan penggunaan OAT pada pasien anak sebesar $100 \%$.

\subsubsection{Tepat dosis}

Tepat dosis adalah pemberian obat sesuai takaran berdasarkan berat badan pasien dibandingkan usia dan frekuensi pemberian yang berpedoman pada guideline. Adapun ketepatan dosis pada pasien dapat dilihat pada Tabel 8. Penggunaan obat subdosis apabila dosis yang diberikan kepada pasien lebih kecil atau kurang dari rentang minimal dosis harian penggunaan OAT pada anak. Sedangkan dikatakan overdosis jika dosis yang diberikan kepada pasien lebih besar atau lebih dari dosis maksimal penggunaan OAT pada anak yang telah ditetapkan oleh Pedoman Nasional Pengendalian Tuberkulosis tahun 2014.

Berdasarkan hasil penelitian tersebut dapat diketahui, penggunaan obat yang tidak tepat dosis sebanyak 5,3\% yaitu mengalami subdosis pada fase pengobatan intensif. Apabila dosis yang diberikan kepada pasien lebih rendah dari dosis yang dianjurkan dapat menyebabkan tidak tercapainya efek obat yang diinginkan. Kurangnya dosis obat yang diberikan atau di bawah 
konsentrasi efektif minimum, dapat memperpanjang lama perawatan dan kesembuhan pasien akan lebih lama. Menurut Fauziyah, dkk., (2012) penggunaan OAT paket KDT yang subdosis dapat mengakibatkan pengobatan TB menjadi kurang optimal dan meningkatnya risiko resistensi OAT. Penggunaan OAT pada pasien dinyatakan subdosis dilihat dari hasil perhitungan matematis, dan pasien yang mengalami subdosis telah dinyatakan sembuh karena menunjukkan perbaikan klinis selama proses pengobatan berlangsung.

Tabel 8. Ketepatan dosis pada pasien TB anak di Instalasi Rawat Jalan RSUD Dr. Moewardi periode 2016-2017. $\mathrm{H}=$ Isoniazid Z= Pirazinamid E= Etambutol

\begin{tabular}{|c|c|c|c|c|c|c|c|c|}
\hline No & No RM & $\begin{array}{c}\text { Bulan } \\
\text { ke-- }\end{array}$ & $\begin{array}{c}\text { Dosis } \\
\text { pemakaian } \\
\text { menurut } \\
\text { resep }\end{array}$ & $\begin{array}{c}\text { Rentang dosis } \\
\text { pemakaian menurut } \\
\text { guideline } \\
(\mathbf{m g} / \mathrm{KgBB} / \mathrm{hari}) \\
\end{array}$ & $\begin{array}{c}\text { Rentang dosis } \\
\text { pemakaian } \\
\text { menurut } \\
\text { resep }\end{array}$ & Keterangan & $\%$ & Paket OAT \\
\hline \multirow[t]{2}{*}{1.} & $012498 x x$ & 1 & $Z=200$ & $30-40$ & $240-320$ & Subdosis & 0,66 & \multirow{2}{*}{ Kombipak } \\
\hline & & 2 & $Z=200$ & $30-40$ & $300-400$ & Subdosis & 0,66 & \\
\hline \multirow[t]{2}{*}{2.} & $012514 x x$ & 1 & $Z=1000$ & $30-40$ & $1080-1440$ & Subdosis & 0,66 & \multirow{2}{*}{ Kombipak } \\
\hline & & 2 & $Z=1000$ & $30-40$ & $1080-1440$ & Subdosis & 0,66 & \\
\hline \multirow[t]{3}{*}{3.} & $013632 x x$ & 1 & $\mathrm{H}=150$ & $7-15$ & $203-435$ & Subdosis & 0,33 & \multirow{2}{*}{ KDT/FDC } \\
\hline & & 1 & $Z=800$ & $30-40$ & $870-1160$ & Subdosis & 0,33 & \\
\hline & & 2 & $Z=600$ & $30-40$ & $900-1200$ & Subdosis & 0,66 & Kombipak \\
\hline \multirow[t]{5}{*}{4.} & $013852 x x$ & 2 & $\mathrm{E}=200$ & $15-25$ & $210-350$ & Subdosis & 0,66 & Kombipak \\
\hline & & 3 & $\mathrm{E}=200$ & $15-25$ & $210-350$ & Subdosis & 0,66 & Kombipak \\
\hline & \multicolumn{2}{|c|}{ Overdosis } & & & & & $\mathbf{0}$ & \\
\hline & \multicolumn{2}{|l|}{ Subdosis } & & & & & \multirow{2}{*}{$\begin{array}{r}5,3 \\
94,7\end{array}$} & \\
\hline & Tepat D & sis & & & & & & \\
\hline
\end{tabular}

Seorang pasien TB dinyatakan sembuh pada penelitian ini, apabila telah menyelesaikan pengobatannya secara lengkap minimal 6 bulan dan ditandai dengan adanya perbaikan klinis. Pengobatan TB yang berhasil akan dapat terlihat dari perubahan klinis pada pasien seperti terjadinya peningkatan berat badan secara signifikan, nafsu makan bertambah, dan pasien jarang sakit tidak seperti pada awal gejala TB misalnya batuk, demam, meriang berkepanjangan.

Berdasarkan penelitian Dewi (2011) di Instalasi Rawat Jalan BKPM Klaten menyatakan bahwa ketepatan dosis dalam penggunan OAT kombipak rifampisin, isoniazid dan pirazinamid pada pasien anak sebesar 95\%. Penelitian Tricahyono (2013) di Balai Besar Kesehatan Paru Masyarakat Surakarta menyatakan bahwa ketidaktepatan dosis pada pasien anak sebesar 3\% terjadi pada pemberian rifampisin baik tahap intensif maupun pada lanjutan.

Keterbatasan pada penelitian ini yaitu penelitian dilakukan secara retrospektif sehingga tidak dapat diketahui efek samping penggunaan OAT yang tidak tepat. Proses pertumbuhan dan perkembangan fisiologis pada pasien anak terjadi sangat dinamis dan kompleks, sehingga dapat mempengaruhi kejadian dan keparahan efek samping obat. Berdasarkan hal itu, perlu dilakukan studi monitoring efek samping OAT pada pasien anak dengan gejala dan terdiagnosis TB serta 
yang menerima terapi TB. Data rekam medis pasien yang kurang lengkap menyebabkan analisis tepat pasien tidak dapat dilakukan. Tidak adanya keterangan pada data rekam medis pasien mengenai kontraindikasi atau kondisi-kondisi khusus yang memerlukan penyesuaian dosis secara individual menyebabkan analisis tepat pasien tidak dapat dilakukan.

\section{Kesimpulan}

Hasil evaluasi penggunaan OAT pada pasien anak di Instalasi Rawat Jalan RSUD Dr. Moewardi menunjukkan bahwa persentase ketepatan obat pada semua fase pengobatan $100 \%$ sesuai dengan Pedoman Nasional Pengendalian Tuberkulosis 2014. Persentase ketepatan dosis sebesar $94,7 \%$. Penggunaan obat yang tidak tepat dosis sebanyak 5,3\% yaitu mengalami subdosis pada fase pengobatan intensif.

\section{Ucapan Terimakasih}

Penulis mengucapkan terima kasih kepada pihak RSUD Dr. Moewardi yang telah memberikan izin untuk melakukan penelitian. Penulis juga mengucapkan terima kasih kepada semua yang telah membantu selama proses penelitian ini berlangsung.

\section{Daftar Pustaka}

Astuti, D. I., 2010. Evaluasi Penggunaan Antituberkulosis Pada Pasien Tuberkulosis Paru di Instalasi Rawat Jalan RSUD Dr. Moewardi Surakarta Tahun 2009, Skripsi Thesis, Universitas Muhammadiyah Surakarta.

Dewi, A. P., 2011. Evaluasi Penggunaan Obat Anti Tuberkulosis Pada Pasien Anak di Instalasi Rawat Jalan Balai Kesehatan Paru Masyarakat Klaten Tahun 2010, Naskah Publikasi, Fakultas Kedokteran, Universitas Muhamadiyah Surakarta.

Dinas Kesehatan Kota Surakarta, 2016. Profil Kesehatan Kota Surakarta Tahun 2016, Dinas Kesehatan Kota Surakarta, Surakarta.

Fauziyah, L., Prabowo, M. H., danWibowo, A., 2012. Pengembangan dan Validasi Metode Analisis Rifampicin Isoniazid-Pirazinamid dalam Fixed Dose Combination dengan Metode Kromatografi Lapis Tipis-Densitometri, Jurnal Ilmiah Farmasi. 9 (2).

Kartasasmita, C. B., 2009. Epidemiologi Tuberkulosis, Sari Pediatri. 11 (2), 124-129.

Kemenkes RI, 2013. Riset Kesehatan Dasar Tahun 2013, Kementrian Kesehatan Republik Indonesia Badan Penelitian dan Pengembangan Kesehatan, Jakarta.

Kemenkes RI, 2014. Pedoman Nasional Pengendalian Tuberkulosis. Kementrian Kesehatan Republik Indonesia Direktorat Jenderal Pengendalian Penyakit dan Penyehatan Lingkungan, Jakarta.

Khoirunisa, Z., 2015. Analisis Pengaruh Ketidaksesuaian Dosis Terhadap Kegagalan Terapi TB Paru di Balai Besar Kesehatan Paru Masyarakat (BBKPM) Surakarta 2012-2014. Tugas Akhir. Fakultas Matematika dan Ilmu Pengetahuan Alam, Universitas Sebelas Maret Surakarta.

Miftahurrahmah, Rahman, A. O., dan Ayudia, E. I., 2014. Pengaruh Terapi Antituberkulosis Terhadap Pertumbuhan Penderita Tuberkulosis Anak di Kota Jambi, JMJ. 2 (2), 178 - 188. 
Muniroh, N., Aisah, S., dan Mifbakhuddin, 2013. Faktor-Faktor yang Berhubungan Dengan Kesembuhan Penyakit Tuberkulosis (TBC) Paru di Wilayah Kerja Puskesmas Mangkang Semarang Barat, Jurnal Keperawatan Komunitas. 1 (01), 33-34.

Priyandani, Y., Fitantri, A. A., Abdani, F. A. N., Ramadhani, N., Nita, Y., Mufarrihah, Setiawan, C. D., Utami, W., Athijah, U., 2014. Profil Problem Terapi Obat Pada Pasien Tuberkulosis di Beberapa Puskesmas Surabaya, Jurnal Farmasi Komunitas. 1 (2), 30-35.

Raharjoe, N. N., Supriyatno, B., Setyanto, D. B. 2008. Buku Ajar Respirologi Anak Edisi Pertama, Ikatan Dokter Anak Indonesia, Jakarta.

Senewe, F.P., 2002. Faktor-Faktor yang Mempengaruhi Kepatuhan Berobat Penderita Tuberkulosis Paru di Puskesmas Depok, Bul. Penel. Kesehatan. (30) (1), 31-38.

Tricahyono, G., 2013, Evaluasi Ketepatan Terapi Terhadap Keberhasilan Terapi Pada Pasien Tuberkulosis di Balai Besar Kesehatan Paru Masyarakat Surakarta Bulan Januari-Juni Tahun 2013, Naskah Publikasi, Fakultas Farmasi, Universitas Muhammadiyah Surakarta. 